\title{
Sources and preservation of organic matter in recent sediment from the Changjiang (Yangtze River) Estuary, China*
}

\author{
XIAOXIA LÜ ${ }^{1}$, SHIKUI ZHAI ${ }^{1}$ and LIFENG NIU ${ }^{2}$ \\ ${ }^{1}$ College of Marine Geo-science, Ocean University of China, Qingdao, Shandong Province, 266003, China. \\ E-mail: luxiaox@163.com \\ ${ }^{2}$ The Normal College, Qingdao University, Qingdao, Shandong Province, 266071, China.
}

\begin{abstract}
SUMMARY: The vertical distributions of bulk and molecular biomarker compositions in the samples from four sediment cores of the Changiiang (Yangtze River) Estuary were determined. The changes in the bulk and molecular compositions with depth suggest that there have been recent changes in the marine autogenic and terrigenous supply. In the site at the boundary of the turbidity maximum (Site 8) and the most southern site (Site 26), the autogenic and allochthonous inputs make almost the same contribution to sedimentary organic matter. In the site close to the river mouth (Site 11), the organic matter mainly comes from the terrestrial input carried by the Changjiang water, whereas, in the most eastern site (Site 17), the organic matter consists of a mixture of recent and ancient Changjiang delta sedimentary residues. Significant downcore fluctuations were observed in the patterns of the bulk and molecular compositions, as well as in several biomarker ratios, which also indicates the different anoxic conditions at different depths of the core besides the source variation. In addition, the distributions of molecular compounds show that the organic matter is a mixture of immature and mature in the sediments of the four cores, which further indicates that the microbial activity is active in anoxic conditions, especially in the surface sediment. The vertical distributions of molecular compounds also show that the autogenic marine organic matter is more easily degraded, and that the molecular compounds evolve from unstable steric configurations to stable ones in the early diagenetic processes.
\end{abstract}

Keywords: bulk parameter, molecular characterization, sediment, hydrocarbon, the Changjiang Estuary.

RESUMEN: FUENTES Y PRESERVACIÓN DE MATERIA ORGÁNICA EN SEDIMENTOS RECIENTES DEL ESTUARIO DEL RÍO YANGTZE, CHINA.- Este artículo analiza la distribución vertical de la composición mayoritaria y de biomarcadores moleculares en muestras de sedimentos de cuatro testigos obtenidos en el estuario del río Yangtze. Los cambios de composición en profundidad sugieren variaciones recientes de los aportes autógenos y terrígenos. En el máximo de turbidez y en sus limites (estación 8) y en la estación más al sur (estación 26), los aportes autógenos y alóctonos tienen casi la misma contribución a la materia orgánica sedimentaria. En la estación próxima a la desembocadura (estación 11), la materia orgánica procede principalmente de los aportes terrestres del río Yangtze, mientras que en la estación situada mas al Este (estación 17), la materia orgánica consiste en una mezcla de aportes recientes del río Yangtze y de residuos sedimentarios de un antiguo delta del mismo río. Fluctuaciones significantes de la composición mayoritaria y molecular, así como de biomarcadores, fueron observadas a lo largo de los testigos, lo cual indica también condiciones de anoxia diferentes a distintas profundidades, aparte de las diferencias en la procedencia de los sedimentos. Además, la distribución de compuestos moleculares muestra que la materia orgánica es una mezcla de sedimentos maduros e inmaduros en los cuatro testigos, lo cual indica que la actividad microbiana es activa en condiciones de anoxia, especialmente en los sedimentos superficiales. La distribución vertical de los compuestos moleculares también muestra que la materia orgánica marina autógena es más fácilmente degradable, y que los compuestos moleculares evolucionan desde configuraciones inestables estéricas a configuraciones estables en las primeras fases de la diagénesis.

Palabras clave: parámetros mayoritarios, caracterización molecular, sedimento, hidrocarburo, estuario del río Yangtze.

*Received January 18, 2005. Accepted July 1, 2005. 


\section{INTRODUCTION}

Estuarine areas are characterized by high primary production and shallow water depth, both of which allow a relatively large fraction of autochthonous and allochthonous organic matter to reach the sea floor and to be ultimately preserved in anoxic sediments (Hedges and Keil, 1995). Estuarine areas are good environments for studying the origin, pathway and fate of sedimentary organic matter due to the rapid accumulation of fine sediments and consequent sealing of these materials from bacterial remineralization (Hedges and Keil, 1999), as well as specific paleoenvironmental conditions (Brassell, 1993). It is essential to determine the relative contribution of different sources of organic carbon to the biogeochemical cycles in estuarine environments to better understand their ecological importance. Bulk, isotopic and/or molecular marker approaches have been applied in order to trace the origin, transport and fate of organic matter from such diverse sources (Meyers and Ishiwatari, 1993; Mannino and Harvey,

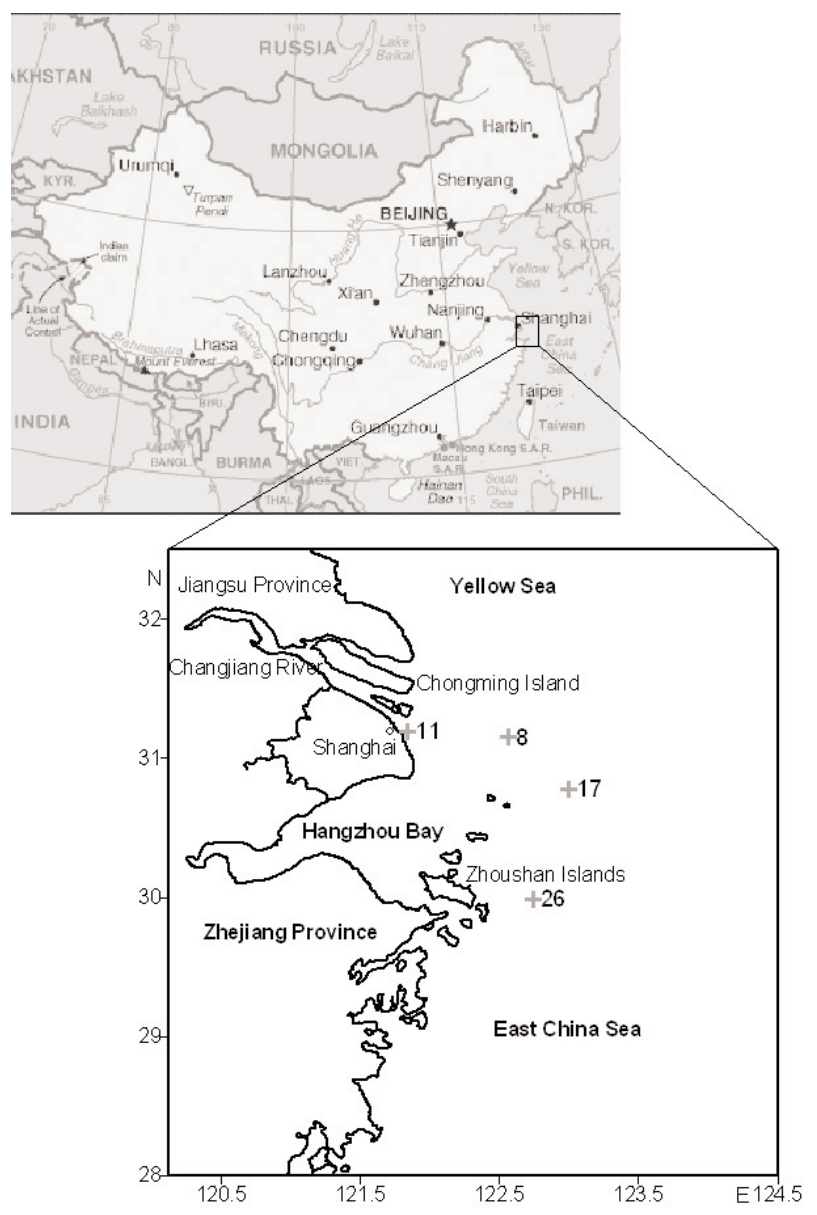

FIG. 1. - Sampling sites of the Changjiang Estuary.
1999). The biomarker approach has also been widely used to interpret changes that occurred within terrestrial ecosystems and to explore the possibility of short-term environmental changes and geochemical processes (Haven et al., 1987; Meyer, 1997).

The Changjiang is the largest river in China, and one of the most important rivers in the world. Its water discharge is the largest in the western Pacific Ocean and the fifth largest in the world, and its sediment load is the fourth largest in the world (Eisma, 1998). Every year, the Changjiang carries more than $4.86 \times 10^{8} \mathrm{t}$ of sediment to the coast via its tremendous discharge, of which about $50 \%$ is deposited in its estuary and the rest is dispersed in the East China Sea (Chen et al., 1988).

The majority of the studies to date on the Changjiang Estuary have focused on water quality and composition, organic matter and nutrient enrichment (Zhao et al., 2001; Chen et al., 2002; Wang et al., 2002). There are few studies on the chemical composition of the organic matter in the estuary sediment. In this respect, this study focuses on determining the compositions, concentrations of bulk geochemical parameters and biomarkers of organic matter in the Changiiang Estuary sediments, to identify the origins and fate of organic matter and also to obtain some information about the environmental change.

\section{MATERIALS AND METHODS}

\section{Sampling Sites}

Sediment samples were collected with a gravity core sampler from the four sites (Sites 8, 11, 17 and 26) in the Changjiang Estuary in June 2003 (Fig. 1). The cores were carefully cut into $2 \mathrm{~cm}$ thick sections and immediately stored at $-20^{\circ} \mathrm{C}$ until further analysis.

In the four sites, Site 11 is located in the area with maximum turbidity at the mouth of the Changjiang Estuary. Site 8 is located on the boundary of the area of maximum turbidity. Site 17 is the most eastern site in the four sites. Site 26 is located in the south of the Changjiang Estuary. The water depth, temperature, salinity and turbidity of overlying water are listed in Table 1.

\section{Sample Analyses}

Sediment samples were freeze-dried, finely ground and homogenized in an agate mill. Dry sediment samples (30 g) were extracted with a mixture 
TABLE 1. - The water depth, temperature, salinity and turbidity of overlying water.

\begin{tabular}{lcccccc}
\hline Site & Longitude $\left({ }^{\circ} \mathrm{E}\right)$ & Latitude $\left({ }^{\circ} \mathrm{N}\right)$ & Water depth $(\mathrm{m})$ & Temperature $\left({ }^{\circ} \mathrm{C}\right)$ & Salinity & Turbidity (FTU) \\
\hline 8 & 122.56 & 31.15 & 22.3 & 17.44 & 31.09 & 116.36 \\
11 & 121.84 & 31.19 & 11.5 & 21.79 & 13.12 & 122.22 \\
17 & 123 & 30.78 & 48.2 & 18.91 & 34.10 & 7.94 \\
26 & 122.74 & 29.99 & 40 & 19.06 & 33.70 & 21.49 \\
\hline
\end{tabular}

of dichloromethane-methanol $(2: 1, \mathrm{v} / \mathrm{v})$ in a Soxhlet extractor for $72 \mathrm{hr}$. The solvent extract was evaporated to $1 \mathrm{~mL}$ and the residue fractionated by column chromatography on alumina over silica gel. The different components, including aliphatic hydrocarbons, aromatic hydrocarbons, ketones, alcohols and non-hydrocarbons (fatty acids and asphaltenes), were obtained by successively eluting with petroleum-ether $(75 \mathrm{~mL})$, benzene $(50 \mathrm{~mL}), 10 \%$ ethyl acetate in hexane $(30 \mathrm{~mL}), 20 \%$ ethyl acetate in hexane $(35 \mathrm{~mL})$ and methanol $(30 \mathrm{~mL})$.

The aliphatic hydrocarbon fractions were analyzed by gas chromatography-mass spectrometry (GC-MS), using a HP 6890N GC interfaced to a HP 5973N MS. The GC column used was a silica capillary column (HP-5 $30 \mathrm{~m} \times 0.25 \mathrm{~mm} \times 0.25 \mu \mathrm{m})$. The temperature was programmed from $80^{\circ} \mathrm{C}$ to $290^{\circ} \mathrm{C}$ at 4 ${ }^{\circ} \mathrm{C} \cdot \mathrm{min}^{-1}$, then maintained for $30 \mathrm{~min}$. Nitrogen was used as the carrier gas. MS operating conditions were: EI ionization, ion source $230^{\circ} \mathrm{C}$, electron energy 70 $\mathrm{eV}$, interface temperature $280^{\circ} \mathrm{C}$. Compound identification was based on the standard spectrogram libraries (NISTO2L) and the individual mass spectra retention times in comparison to published MS data (e.g. Volkman et al., 1990; Logan and Eglinton, 1994; Mangelsdorf and Rullkötter, 2003).

The total organic carbon (TOC) content of each sample was determined using the method in "The Specification for Marine Monitoring" (HY003.191 HY/T 003.10-91) (1991). The total nitrogen (TN) content was determined using the method described in detail by Lü et al. (2005). The organic carbon isotopic composition $\left(\delta^{13} \mathrm{C}\right)$ of sediment samples was determined using a MAT 252 isotope ratio mass spectrometer after they were decarbonated with $10 \% \mathrm{HCl} . \delta^{13} \mathrm{C}$ values are relative to PDB.

\section{RESULTS AND DISCUSSION}

\section{Bulk Geochemical Parameters}

The vertical distributions of TOC, TN, and dissolvable organic matter (DOM) content as well as the atomic ratio $\mathrm{C} / \mathrm{N}$ and $\delta^{13} \mathrm{C}$ are plotted in Figure 2.

The TOC contents vary from 0.39 to $0.95 \%$ in the four core sediments, and their average contents are similar (Table 2), which is lower than those in other coastal sediments (Gonzlez-Vila et al., 2003; Nieuwenhuize et al., 1994). The vertical distributions of TOC and TN are different in the four sites. In Site 8 , the TOC content decreases rapidly in the upper layer of $16 \mathrm{~cm}$, then increases and is the highest at a depth of $74 \mathrm{~cm}$, and then decreases slowly under a depth of $109 \mathrm{~cm}$. In Sites 11 and 26, the TOC content slowly increases in the upper layer of $16 \mathrm{~cm}$ and 74 $\mathrm{cm}$ respectively, and then decreases downwards. In Site 17, the TOC content increases downwards.

The TN in marine sediment is considered indicative of the contribution of aquatic flora (GonzálezVila et al., 2003). Where the TN content is higher, the contribution of aquatic flora is thought to be higher. The average TN content is different from that of TOC, which is highest in Site 8, and lowest in Site 17, and the TOC in Site 26 sediment is higher than in Site 11 (Table 2). The different TN content suggests that the marine flora input in the four sites decreases according to the order of Sites 8, 26, 11 and 17. The vertical distribution of TN is also different in the four sites, which shows the different aquatic input in different geological periods to a certain extent. In Site 8, the distribution of TN content is contrary to that of TOC in the upper layer of 40 $\mathrm{cm}$, but similar to it going downwards. The TN content in Site 11 continuously decreases downwards. In Site 17, the TN content also increases slowly downwards, which is similar to that of TOC. In Site 26 , the TN content increases rapidly in the upper 16 $\mathrm{cm}$, then stays stable at a depth of $74 \mathrm{~cm}$, and then decreases downwards.

The dissolvable organic matter (DOM) content is highest in Site 8 and lowest in Site 26 (Table 2). The DOM content in Site 11 is similar to that in Site 17. In Site 8, the lipid content increases rapidly in the upper $40 \mathrm{~cm}$, then decreases, after that it continues to increase slowly downwards. The distribution of lipids is contrary to that of TOC in Site 11. In Site 17, the lipid content is higher in surface sediment, 

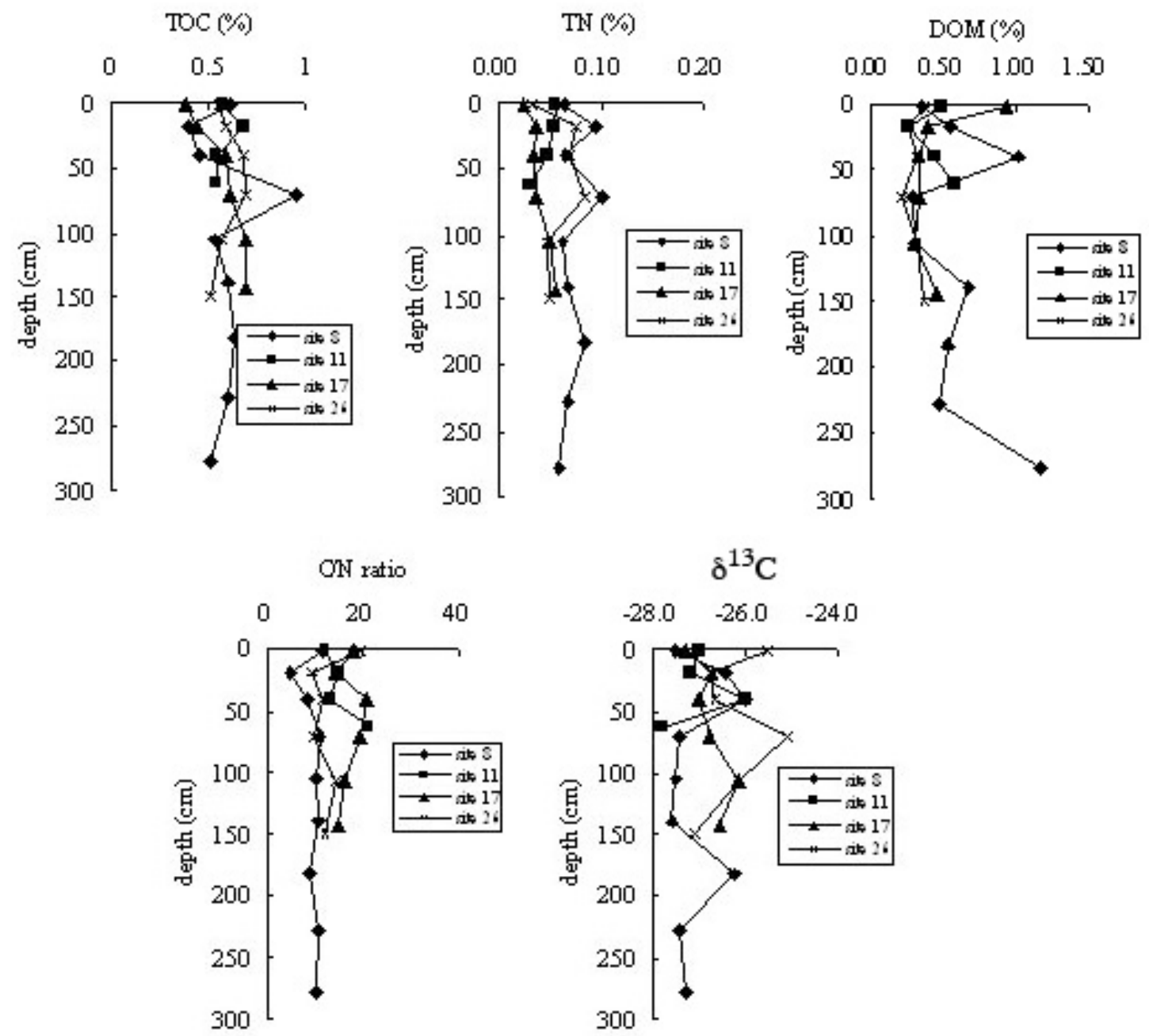

FIG. 2. - The vertical distributions of TOC, TN, and lipid content as well as the atomic ratio $\mathrm{C} / \mathrm{N}$ and $\delta^{13} \mathrm{C}(\mathrm{TOC}$ : total organic carbon; $\mathrm{TN}$ : total nitrogen; DOM: dissolvable organic matter extracted relative to TOC; $\mathrm{C} / \mathrm{N}$ : atomic carbon/nitrogen ratio).

and stays relatively invariable under the layer at 16 $\mathrm{cm}$. In Site 26, the distribution of lipids is the opposite to that of TN. Obviously, the DOM content is higher in the surface sediment except in Site 8. The different distribution of DOM suggests that the DOM content is not simply dependent upon the TOC or the TN content.

The atomic $\mathrm{C} / \mathrm{N}$ ratios have been widely used to distinguish the origin of organic matter $(\mathrm{OM})$ in estuaries based on the generalization that fresh marine autogenic organic matter has atomic $\mathrm{C} / \mathrm{N}$ ratios between 4 and 10, whereas organic matter from terrestrial vascular plants has $\mathrm{C} / \mathrm{N}$ ratios of 20 and greater (Meyers, 1994; Verardo and McIntyre, 1994; Twichell et al., 2002). However, the selective degradation or the different minerals in sediments can affect the $\mathrm{C} / \mathrm{N}$ ratios of organic matter (Lehmann et al., 2002; Müller, 1977). The average

TABLE 2. - The range and average of the bulk geochemical parameters.

\begin{tabular}{|c|c|c|c|c|c|c|}
\hline Site & & TOC (\%) & $\mathrm{TN}(\%)$ & $\operatorname{DOM}(\%)$ & $\mathrm{C} / \mathrm{N}$ & $\delta^{13} \mathrm{C}(\% \circ \mathrm{PDB})$ \\
\hline \multirow{2}{*}{8} & Range & $0.40 \sim 0.95$ & $0.060 \sim 0.10$ & $0.29 \sim 1.2$ & $4.92 \sim 11.3$ & $-27.6 \sim-26.0$ \\
\hline & Average & 0.59 & 0.074 & 0.59 & 9.42 & -27.0 \\
\hline \multirow[t]{2}{*}{11} & Range & $0.54 \sim 0.68$ & $0.029 \sim 0.054$ & $0.26 \sim 0.57$ & $12.3 \sim 21.4$ & $-27.8 \sim-26.0$ \\
\hline & Average & 0.58 & 0.046 & 0.44 & 15.6 & -27.0 \\
\hline \multirow[t]{2}{*}{17} & Range & $0.39 \sim 0.69$ & $0.025 \sim 0.054$ & $0.30 \sim 0.92$ & $14.8 \sim 20.7$ & $-27.3 \sim-26.1$ \\
\hline & Average & 0.57 & 0.039 & 0.46 & 17.5 & -26.7 \\
\hline \multirow[t]{2}{*}{26} & Range & $0.51 \sim 0.69$ & $0.033 \sim 0.085$ & $0.21 \sim 0.37$ & $9.21 \sim 19.7$ & $-27.1 \sim-25.1$ \\
\hline & Average & 0.60 & 0.060 & 0.31 & 12.7 & -26.2 \\
\hline
\end{tabular}


TABLE 3. - The correlation coefficient $(\gamma)$ between $\mathrm{C} / \mathrm{N}$ ratios and $\delta^{13} \mathrm{C}$ values of organic matter.

\begin{tabular}{lcccc}
\hline Site & 8 & 11 & 17 & 26 \\
\hline$\gamma$ & -0.74 & -0.74 & -0.52 & 0.31 \\
\hline
\end{tabular}

$\mathrm{C} / \mathrm{N}$ ratio is highest in Site 17 and lowest in Site 8; the $\mathrm{C} / \mathrm{N}$ ratio in Site 11 is higher than in Site 26. The different $\mathrm{C} / \mathrm{N}$ ratios in the four Sites show that there is much more terrestrial input in Site 17, which is the furthest away from the mouth of Changjiang Estuary. The result suggests that there must be other organic matter input in Site 17. Jin (1992) found that the sediment in northern East China Sea mainly comes from the mixture of recent and the residues from the ancient Changjiang delta, so the higher $\mathrm{C} / \mathrm{N}$ ratio might be due to the residue sediment. The vertical distributions of the $\mathrm{C} / \mathrm{N}$ ratios in the four sites have different characteristics. In Site 8 , the $\mathrm{C} / \mathrm{N}$ ratio decreases in the upper layer of $16 \mathrm{~cm}$, then increases inside the layer of $74 \mathrm{~cm}$, and then remains relatively invariable. In Site 11 , the $\mathrm{C} / \mathrm{N}$ ratio increases downwards. In Site 17 , the $\mathrm{C} / \mathrm{N}$ ratio decreases in the upper layer of $16 \mathrm{~cm}$, and then increases rapidly to $40 \mathrm{~cm}$, after that it decreases slowly downwards. In Site 26, the $\mathrm{C} / \mathrm{N}$ ratio is high-
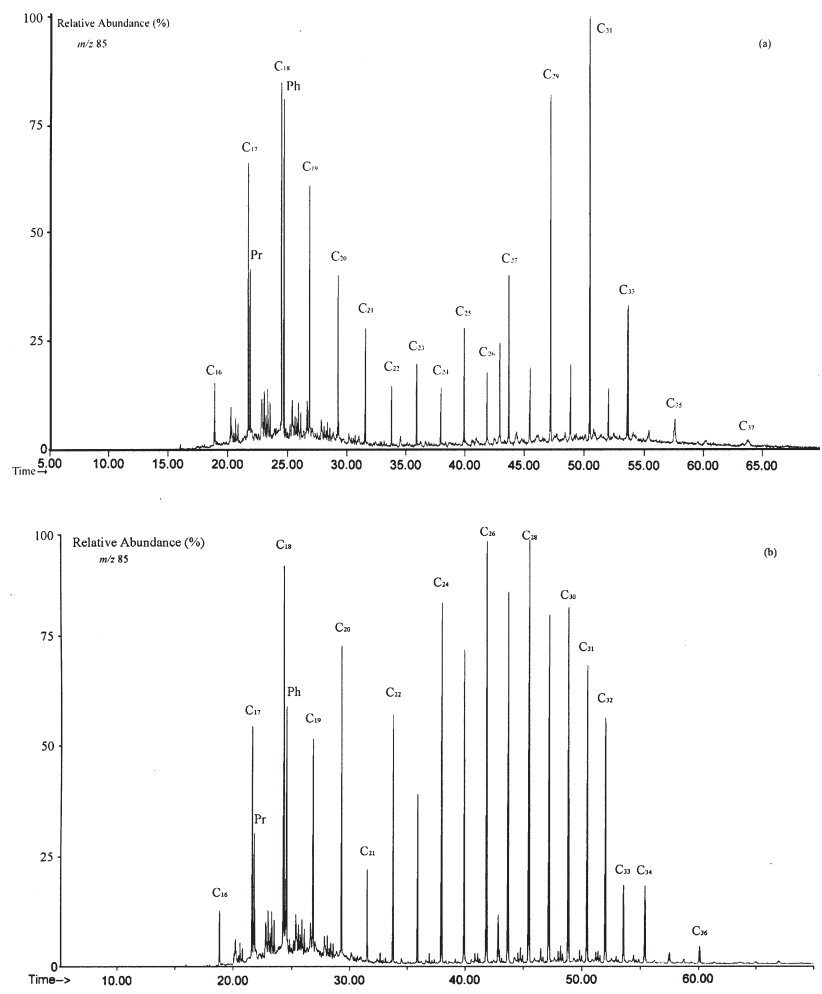

er in the surface sediment, and then continues to slowly increase. The different vertical distributions of $\mathrm{C} / \mathrm{N}$ ratios in the sediment from the four sites may be due to the complex organic matter origins and different circumstances. Obviously, the $\mathrm{C} / \mathrm{N}$ ratios in the surface sediment is higher except in Site 11, which suggests that there is a high terrestrial vascular plant organic matter input in the three sites. The lower $\mathrm{C} / \mathrm{N}$ ratio in the surface sediment of Site 11 might be due to the selective degradation of nitrogen for the active bacterial activity in the other three sites and the particular turbidity conditions in Site 11 (Jin, 1992).

The $\delta^{13} \mathrm{C}$ value of organic matter has proven to be an effective proxy indicator to trace biogeochemical cycling in marine and lacustrine environments (Ostrom et al., 1997; Hodell and Schelske, 1998), though it changes little during long sedimentary processes (Lehmann et al., 2002). The $\delta^{13} \mathrm{C}$ value in Site 8 is similar to that in Site 11, and both average values are lowest in the four sites, and highest in Site 26 (Table 2). The different average contents of the $\delta^{13} \mathrm{C}$ value of organic matter suggest that there is much more terrestrial organic matter input in Site 8 and 11 . Generally, the $\delta^{13} \mathrm{C}$ values of organic matter appear negative in relation to the $\mathrm{C} / \mathrm{N}$ ratios in the same condition if the organic matter has not passed
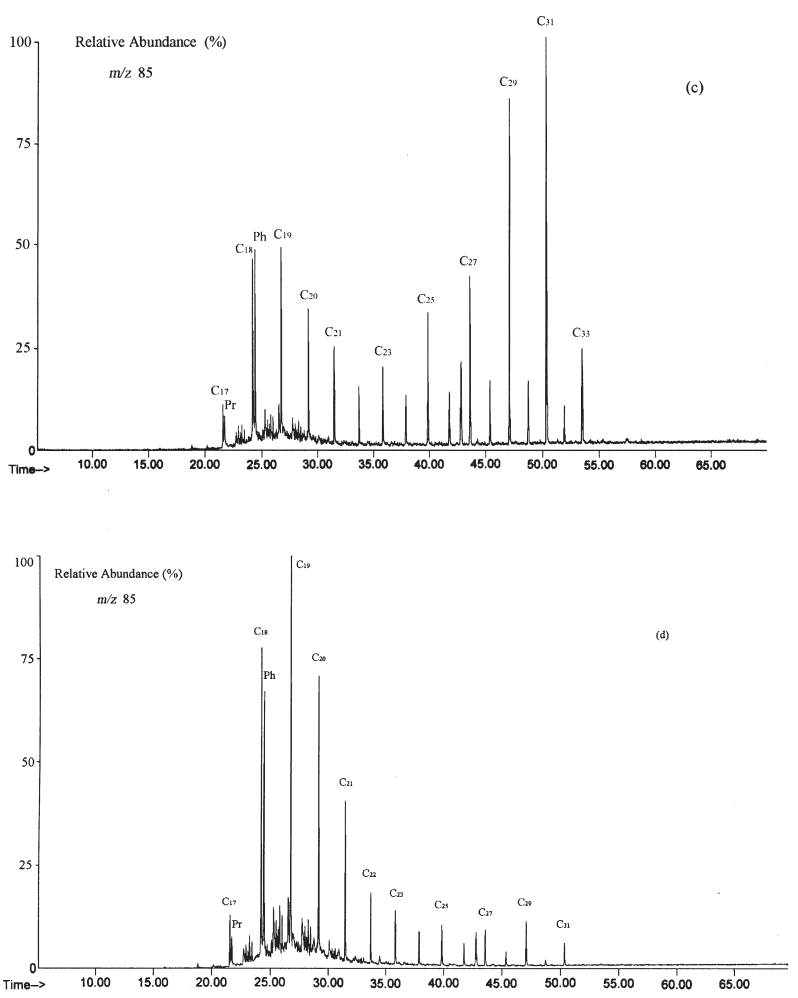

FIG. 3. - GC-MS mass chromatograms of $\mathrm{m} / \mathrm{z} 85$ of a representative aliphatic hydrocarbon fraction from Site 8 (14-22 cm) (a), Site 17 (sur face sediment) (b), Site $11(36-44 \mathrm{~cm})(\mathrm{c})$ and Site 26 (surface sediment) (d). 
through complex degradation (Harada et al., 1995; Freudenthal et al., 2001; Twichell et al., 2002). The distributions of $\delta^{13} \mathrm{C}$ values appear negative in relation to $\mathrm{C} / \mathrm{N}$ ratios in the four sites except in Site 26 (Fig. 2 and Table 3). In Site 26, the $\delta^{13} \mathrm{C}$ has the same distribution as the $\mathrm{C} / \mathrm{N}$ ratios in the upper layer of $48 \mathrm{~cm}$, then the opposite distribution appears in the layer at $106 \mathrm{~cm}$, and then the similar distribution appears again. The quick decrease in the $\mathrm{C} / \mathrm{N}$ ratio in the upper layer of core 26 may be due to the selective degradation of nitrogen in rich autogenic organic matter. The different correlativity between $\delta^{13} \mathrm{C}$ values and $\mathrm{C} / \mathrm{N}$ ratios suggests that the organic matter in the four sites has different origins or undergoes complex degradation processes.

\section{Biomarker distributions}

\section{n-Alkanes}

The aliphatic hydrocarbons in the sediments from the four sites comprise a bimodal distribution of $n$-alkanes ranging from $\mathrm{C}_{15}$ to $\mathrm{C}_{37}$, with the maxima at $\mathrm{C}_{18}$ or $\mathrm{C}_{19}$ and $\mathrm{C}_{29}$ or $\mathrm{C}_{31}$ except in the surface sediment of Site 17 (Fig. 3). The clear odd/even carbon number predominance of longer chain $n$-alkanes $\left(\mathrm{CPI}_{2}\right)$ indicates that the sample material did not pass through extensive diagenesis except in the surface sediment of Site 17 (Fig. 4 and Table 4). A strong odd predominance in the $n-\mathrm{C}_{27}$ to $\mathrm{C}_{31}$ range alkanes is usually related to the input of wax lipids derived from higher plants, although long chain $n$ alkanes may also originate from sea grasses and diatoms (Volkman, 1986; Jaffé et al., 1995). Shorter chain $n$-alkanes with maxima at $\mathrm{C}_{15}, \mathrm{C}_{17}$ and $\mathrm{C}_{21}$ are derived from lipids synthesized by phytoplankton and benthic algae (Cranwell et al., 1987; Canuel et al., 1997). The shorter chain $n$-alkanes have no odd/even carbon number predominance $\left(\mathrm{CPI}_{1}\right)$ in any of the samples of the four sites, which suggests that fossil fuel inputs might be an important source of these alkanes or the autogenic shorter chain $n$ alkanes have passed through preferential degradation during early diagenesis (González-Vila et al., 2003). Obviously, the $\mathrm{CPI}_{2}$ of $n$-alkanes in the surface sediment of the four cores is usually the lowest, and the $\mathrm{CPI}_{1}$ in surface sediments is also lower than that in subsurface ones in the four sites (Fig. 4). These results suggest that there might be much more fossil fuel input to sediments carried by the Yangtze River water or in aerosol forms from anthropogenic pollution in recent years, or that the bacterial activities are more active in the surface sediment which results in the extensive degradation of n-alkanes, especially in Site 17. In addition, the especially low $\mathrm{CPI}_{2}(0.85)$ of $n$-alkanes in the surface sediment of Site 17 might also be due to fossil fuel pollution (Medeiros and Bícego, 2004). In the four sites, the CPI variation is extensive in the upper layer (Fig. 4), which suggests the environment is changeful in the shallow coast due to hydrodynamics, bioturbation and the burrowing of benthos or the different fossil fuel inputs in different periods (Lü and Song, 2004). It is worth noting that the $n$-alkanes from $\mathrm{C}_{18}$ to $\mathrm{C}_{22}$ in the surface sediment of Site 17 exhibit a predominance of even-carbon number predominance with
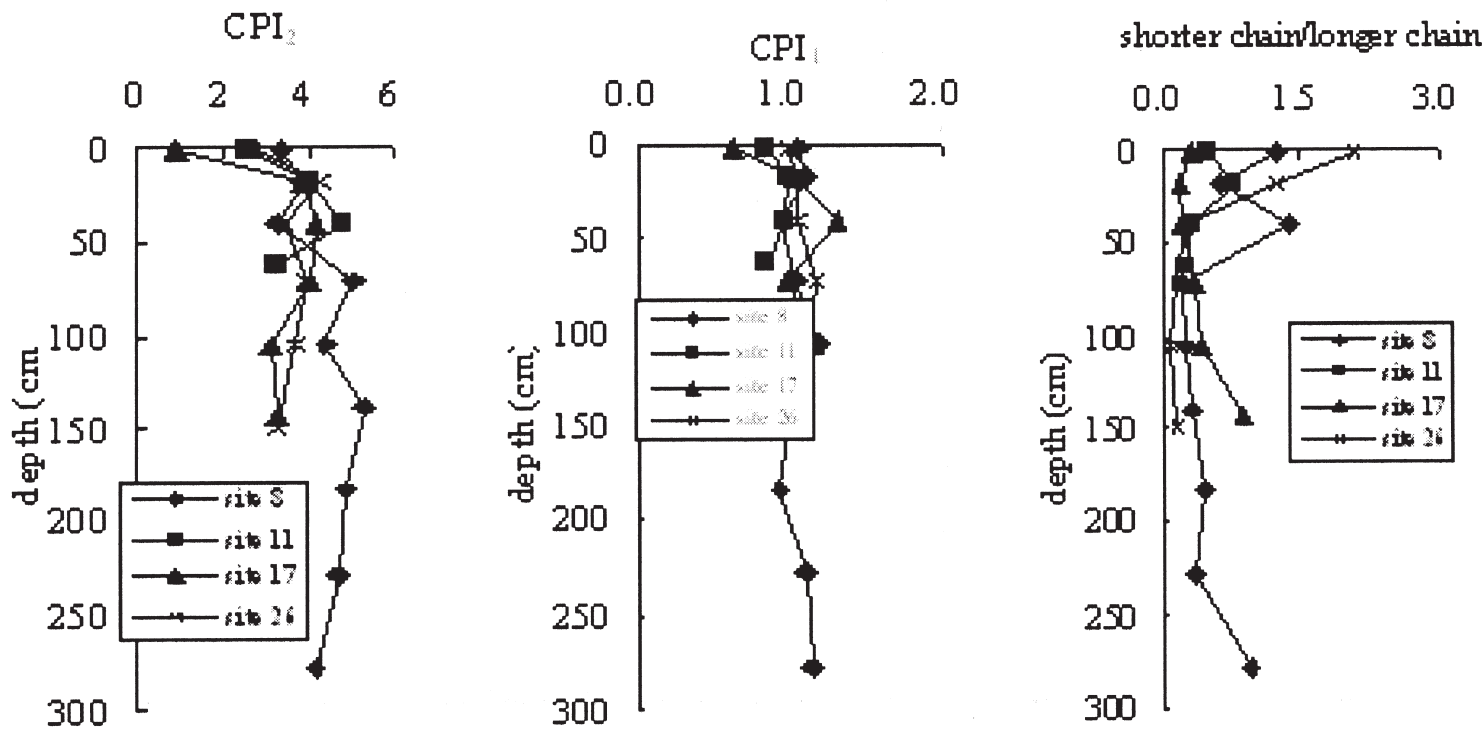

FIG. 4. - Downcore plots of $n$-alkanes $\left(\mathrm{CPI}_{2}=\mathrm{CPI}_{27-33}, \mathrm{CPI}_{1}=\mathrm{CPI}_{17-21}\right.$, shorter chain/longer chain). 
TABLE 4. - Analytical data of n-alkanes and isoprenoid hydrocarbons.

\begin{tabular}{|c|c|c|c|c|c|}
\hline Site & & 8 & 11 & 17 & 26 \\
\hline \multirow[t]{2}{*}{$\mathrm{CPI}_{25-33}$} & Range & $3.31-5.26$ & $2.54-4.77$ & $0.85-4.18$ & $2.75-4.32$ \\
\hline & Average & 4.34 & 3.66 & 3.21 & 3.58 \\
\hline \multirow{2}{*}{$\mathrm{CPI}_{15-21}$} & Range & $0.93-1.20$ & $0.85-1.00$ & $0.65-1.32$ & $0.99-1.16$ \\
\hline & Average & 1.06 & 0.92 & 1.03 & 1.08 \\
\hline \multirow{2}{*}{$\Sigma \mathrm{C} 1_{5-20} / \Sigma \mathrm{C}_{21-37}$} & Range & $0.23-1.36$ & $0.25-0.75$ & $0.18-0.87$ & $0.10-2.08$ \\
\hline & Average & 0.64 & 0.46 & 0.39 & 0.67 \\
\hline \multirow{2}{*}{$\mathrm{Pr} / \mathrm{Ph}$} & Range & $0.07-0.67$ & $0.07-0.16$ & $0.05-0.51$ & $0.06-0.11$ \\
\hline & Average & 0.27 & 0.11 & 0.24 & 0.08 \\
\hline \multirow{2}{*}{$\mathrm{Pr} / \mathrm{C}_{17}$} & Range & $0.38-0.62$ & $0.70-0.80$ & $0.44-1.00$ & $0.25-0.70$ \\
\hline & Average & 0.54 & 0.75 & 0.63 & 0.51 \\
\hline \multirow{2}{*}{$\mathrm{Ph} / \mathrm{C}_{18}$} & Range & $0.82-1.00$ & $0.92-1.08$ & $0.64-1.02$ & $0.75-1.18$ \\
\hline & Average & 0.90 & 1.00 & 0.83 & 0.89 \\
\hline
\end{tabular}

$\mathrm{CPI}_{18-22}$ 1.86. The even-carbon number predominance of short chain $n$-alkanes might suggest the bacterial origin of the organic matter (Grimalt and Albaigés, 1987).

The $\Sigma \mathrm{C}_{15-20} / \Sigma \mathrm{C}_{21-37}$ ratios (shorter chain/longer chain) usually serve as a measure of the relative proportions of autochthonous and allochthonous organic matter inputs. Higher values are thought to be predominant in marine sources, whereas lower values are diagnostic of non-marine sources (Duan, 2000; Muri et al., 2004). The average $\Sigma \mathrm{C}_{15-20} / \Sigma \mathrm{C}_{21-37}$ ratios in the four sites are all higher in the upper layer (Fig. 4). The average $\Sigma \mathrm{C}_{15-20} / \Sigma \mathrm{C}_{21-37}$ ratios decrease according to the order of Site 26,8,11 and 17, which is consistent with the results obtained from the $\mathrm{C} / \mathrm{N}$ ratios. The different distributions of $\Sigma \mathrm{C}_{15-20} / \Sigma \mathrm{C}_{21-37}$ ratios in the four cores suggest that there are more autogenic organic matter inputs in the surface sediments of Site 26 and 8, and the terrestrial input is the dominant source of organic matter in the deep layer, and that the organic matter in Site 17 mainly originates from the allochthonous input. The result is consistent with the environment of each site. Site 11 is in the turbidity maximum and at the mouth of the Changjiang Estuary, where water depth is shallow and salinity is low (Table 1); there is much more terrestrial matter accumulated here (Chen et al., 2001). Site 8 is on the boundary of the turbidity maximum, the turbidity of upper layer water is lower and the salinity is much higher than in Site 11; therefore, marine organisms in this site grow better than in Site 11. Site 26 is located on the east of the Zhoushan Islands, where the turbidity of overlying water is lower and the salinity is higher, so the marine organisms grow well. Therefore, there would be much more organic particles that subside to the bottom. In Site 17, sediment mainly comes from the residue matters from the ancient Changjiang delta (Jin, 1992), and the $\Sigma C_{15-20} / \Sigma C_{21-37}$ ratios show the characteristics of terrestrial plants. In addition, due to active bacterial activities and the relative oxidative condition in the upper layer, the marine autogenic matter degrades more quickly, so the $\Sigma \mathrm{C}_{15-20} / \Sigma \mathrm{C}_{21-37}$ ratios increase downwards, which is consistent with the vertical distributions of TOC and $\mathrm{TN}$ in this site.

\section{Isoprenoid hydrocarbons}

Pristane and phytane are thought to mainl originate from the geologic alteration of the phytol side chain of chlorophyll although chromans and/or tocopherols have been suggested to be additional potential sources (Haven ten et al., 1987; Peters and Moldowan, 1993; Li et al., 1995). The pristane/phytane $(\mathrm{Pr} / \mathrm{Ph})$ ratio is generally thought to be an indicator of depositional conditions and the relative degree of alteration or degradation of organic matter as well as the pristane $/ \mathrm{C}_{17}$ and phytane $/ \mathrm{C}_{18}$ ratios for ancient sediment (Didyk et al., 1978; Harada et al., 1995). In recent sediment, the $\mathrm{Pr} / \mathrm{Ph}$ ratio is usually used to identify the organic matter sources (Medeiros et al., 2005). In uncontaminated sediments, the $\mathrm{Pr} / \mathrm{Ph}$ ratio is higher than 1 and typically between 3 and 5 (Steinhauer and Boehm, 1992). In the four sites, the $\mathrm{Pr} / \mathrm{Ph}$ ratios are all below one though the vertical distributions are different (Fig. 5), which suggests a source of main petroleum products (Medeiros et al., 2005). The $\mathrm{Pr} / \mathrm{Ph}$ ratio variation in the depth might also depend on the different anoxic conditions besides the source difference (Volkman and Maxwell, 1986). The $\mathrm{Pr} / \mathrm{C}_{17}$ and the $\mathrm{Ph} / \mathrm{C}_{18}$ ratios are in the range of 0.25 to 1.00 and 0.64 to 1.18 respectively. These results may reflect the microbial activity in the four cores, which is particularly strong in some layers, independently of the prevalent source of the organic matter and the oxygenic factors (González-Vila et al., 2003). 

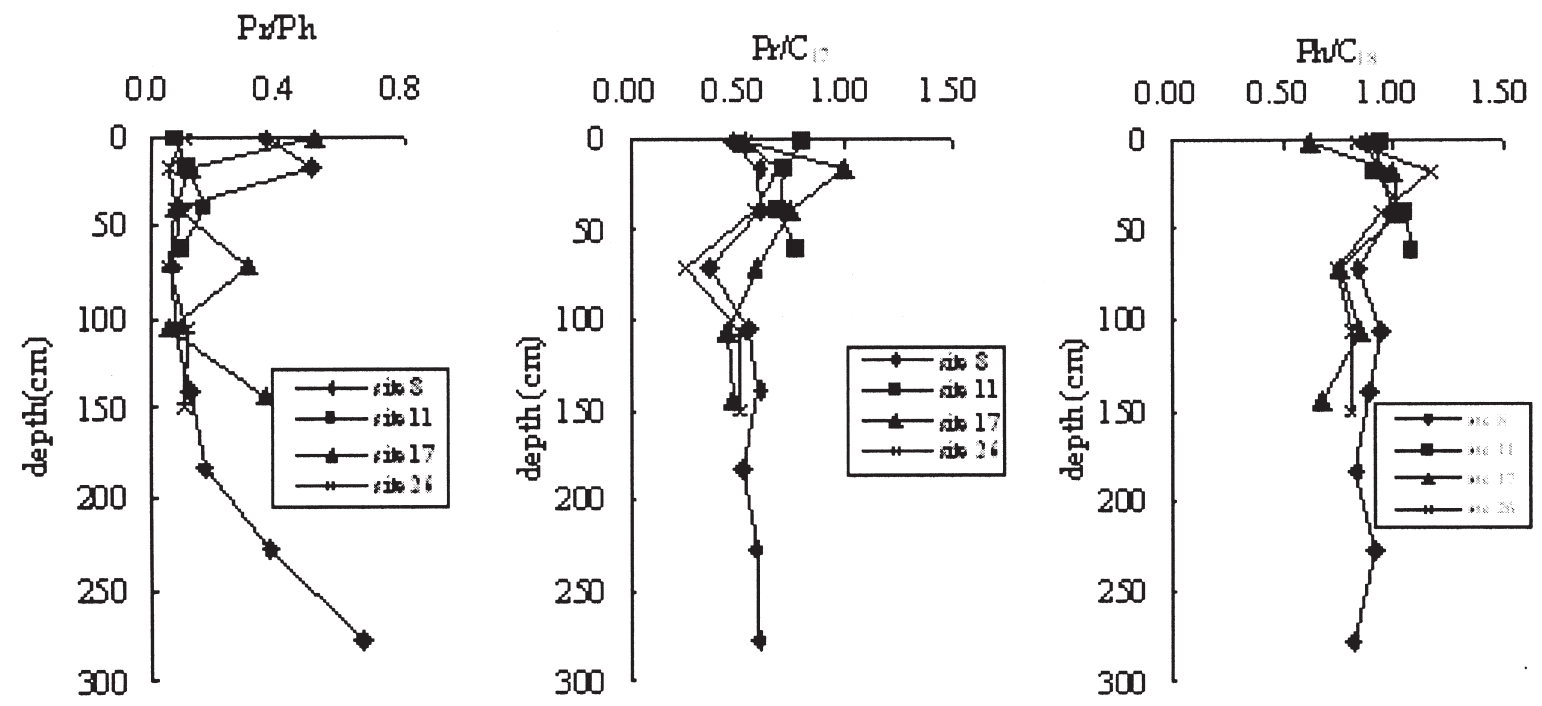

FIG. 5. - Downcore plots of isoprenoid hydrocarbons ( $\mathrm{Pr} / \mathrm{Ph}, \mathrm{Pr} / \mathrm{C}_{17}, \mathrm{Ph} / \mathrm{C}_{18}$ ).

\section{Hopanoid hydrocarbons and steranes}

Hopanes are the most significant class of saturated hydrocarbons in the Changjiang Estuary sediment, followed by steranes. Diasteranes and pregnanes are present only in small amounts (Fig. 6 and
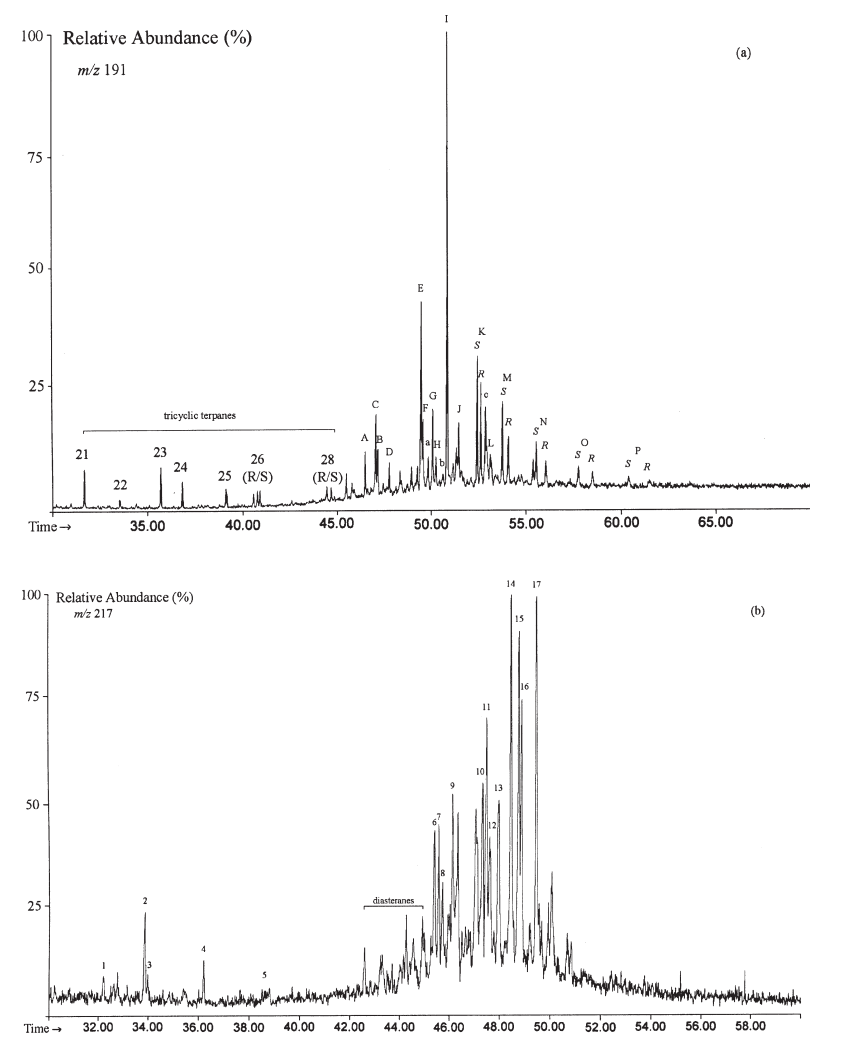

FIG. 6. - GC/MS mass chromatograms of (a) m/z 191 (polycyclic terpanes) and (b) $\mathrm{m} / \mathrm{z} 217$ (steranes) of a representative aliphatic hydrocarbon fraction (Site 8, 0-2 cm). Peak assignments correspond to compound names in Table 5.
Table 5). The petroleum biomarkers mainly come from the terrestrial input carried by the Changjiang water. Many biomarkers are subsided at the mouth

TABLE 5. - Compounds identified in the $\mathrm{m} / \mathrm{z} 191$ mass chromatogram of the aliphatic hydrocarbon fraction of the surface sediment (8-1) from Site 8.

\begin{tabular}{|c|c|}
\hline Symbol & Component \\
\hline A & $18 \alpha-22,29,30$-trinorneohopane \\
\hline $\mathrm{B}$ & $17 \alpha-22,29,30$-trinorhopane \\
\hline $\mathrm{C}$ & 22,29,30-trinor-hop-5(6)-ene \\
\hline $\mathrm{D}$ & $17 \beta-22,29,30$-trinorhopane \\
\hline $\mathrm{E}$ & $17 \alpha, 21 b-30$-norhopane \\
\hline $\mathrm{F}$ & 30-norneo-hopane \\
\hline G & Hop-2(3)-ene \\
\hline $\mathrm{H}$ & $17 \beta, 21 \alpha-30$-norhopane \\
\hline I & $17 \alpha, 21 \beta$-hopane \\
\hline $\mathrm{J}$ & $17 \beta, 21 \alpha$-hopane \\
\hline $\mathrm{K}_{\mathrm{SPR}}$ & $17 \alpha, 21 \beta$-homohopane (22S and 22R) \\
\hline $\mathrm{L}^{-3 / \mathrm{K}}$ & $17 \beta, 21 \beta$-hopane \\
\hline$M_{S R}$ & $17 \alpha, 21 \beta$-bishomohopane (22S and 22R) \\
\hline $\mathrm{N}_{\mathrm{S} / \mathrm{R}}^{\mathrm{S}}$ & $17 \alpha, 21 \beta$-trishomohopane (22S and $22 \mathrm{R})$ \\
\hline $\mathrm{O}_{\mathrm{S} / \mathrm{R}}^{\mathrm{S} / \mathrm{R}}$ & $17 \alpha, 21 \beta$-tetrakishomohopane ( $22 \mathrm{~S}$ and $22 \mathrm{R}$ ) \\
\hline $\mathrm{P}_{S / \mathrm{R}}^{\mathrm{S} / \mathrm{t}}$ & $17 \alpha, 21 \beta$-pentakishomohopane ( $22 \mathrm{~S}$ and $22 \mathrm{R})$ \\
\hline$a^{3 / K}$ & Lupane \\
\hline $\mathrm{b}$ & Oleanane \\
\hline $\mathrm{c}$ & Gammacerane \\
\hline 1 & $5 \beta$-pregnane \\
\hline 2 & $5 \alpha$-pregnane \\
\hline 3 & $5 \beta$-homopregnane \\
\hline 4 & $5 \alpha$-homopregnane \\
\hline 5 & $5 \alpha$-bishomopregnane \\
\hline 6 & $5 \alpha, 14 \alpha, 17 \alpha-(20 S)$-cholestane \\
\hline 7 & $5 \alpha, 14 \beta, 17 \beta-(20 R)$-cholestane \\
\hline 8 & $5 \alpha, 14 \beta, 17 \beta-(20 S)$-cholestane \\
\hline 9 & $5 \alpha, 14 \alpha, 17 \alpha-(20 R)$-cholestane \\
\hline 10 & $5 \alpha, 14 \alpha, 17 \alpha-(20 S)-24$-methyl cholestane \\
\hline 11 & $5 \alpha, 14 \beta, 17 \beta-(20 \mathrm{R})-24$-methyl cholestane \\
\hline 12 & $5 \alpha, 14 \beta, 17 \beta-(20 S)-24$-methyl cholestane \\
\hline 13 & $5 \alpha, 14 \alpha, 17 \alpha-(20 \mathrm{R})-24-$ methyl cholestane \\
\hline 14 & $5 \alpha, 14 \alpha, 17 \alpha-(20 S)-24$-ethyl cholestane \\
\hline 15 & $5 \alpha, 14 \beta, 17 \beta$-(20R)- 24 -ethyl cholestane \\
\hline 16 & $5 \alpha, 14 \beta, 17 \beta-(20 S)-24$-ethyl cholestane \\
\hline 17 & $5 \alpha, 14 \alpha, 17 \alpha-(20 \mathrm{R})-24$-ethyl cholestane \\
\hline
\end{tabular}


TABLE 6. - Ranges and average values of hopane and sterane parameters in the four cores of the Changjiang Estuary.

\begin{tabular}{|c|c|c|c|c|c|c|c|c|c|}
\hline \multicolumn{2}{|c|}{ Biomarker parameters } & $\begin{array}{c}8 \\
\text { Range }\end{array}$ & Average & $\begin{array}{c}11 \\
\text { Range }\end{array}$ & Average & $\begin{array}{c}17 \\
\text { Range }\end{array}$ & Average & $\begin{array}{c}26 \\
\text { Range }\end{array}$ & Average \\
\hline Hopanes & $\mathrm{Tm} / \mathrm{Ts}$ & $1.05-1.38$ & 1.20 & $1.27-1.61$ & 1.42 & $0.71-1.36$ & 1.15 & $1.07-1.45$ & 1.25 \\
\hline & $17 \beta(\mathrm{H}) / \mathrm{Ts}$ & $0.50-3.63$ & 1.72 & $0.94-3.26$ & 1.72 & $0.89-5.86$ & 3.85 & $1.00-4.73$ & 3.17 \\
\hline & $\mathrm{C}_{27}$ hopene/Ts & $0.13-10.69$ & 3.78 & $0.28-1.11$ & 0.67 & $4.39-8.29$ & 6.58 & $1.20-12.20$ & 6.67 \\
\hline \multirow{4}{*}{ Steranes } & $22 \mathrm{~S} / 22(\mathrm{~S}+\mathrm{R})$ & $0.28-0.58$ & 0.47 & $0.32-0.53$ & 0.45 & $0.18-0.56$ & 0.34 & $0.20-0.53$ & 0.33 \\
\hline & $\begin{array}{c}\mathrm{C}_{22} \alpha \alpha \alpha \text {-sterane } \\
20 \mathrm{~S} / 20(\mathrm{~S}+\mathrm{R}) \\
\mathrm{C}_{20} \text {-sterane }\end{array}$ & $0.38-0.64$ & 0.47 & $0.24-0.38$ & 0.34 & $0.28-0.49$ & 0.40 & $0.36-0.42$ & 0.39 \\
\hline & $\alpha \beta \beta /(\alpha \beta \beta+\alpha \alpha \alpha)$ & $0.28-0.41$ & 0.36 & $0.30-0.37$ & 0.34 & $0.31-0.38$ & 0.33 & $0.30-0.46$ & 0.35 \\
\hline & $\mathrm{C}_{27} / \mathrm{C}_{29}$ & $0.36-1.26$ & 0.69 & $0.81-1.31$ & 1.11 & $0.56-1.26$ & 0.87 & $0.60-0.91$ & 0.77 \\
\hline
\end{tabular}

$\mathrm{C}_{27} / \mathrm{C}_{29}=\mathrm{C}_{27}$-sterane $(\alpha \beta \beta+\alpha \alpha \alpha) / \mathrm{C}_{29}$-sterane $(\alpha \beta \beta+\alpha \alpha \alpha)$

of the Estuary and only a few are transported to the southeast and the east by the water current (Lü and Zhai, 2005). The occurrence of hopanes and the $17 \beta-22,29,30$-trinorhopane, both of which indicate an early diagenetic stage, simultaneously with $17 \beta$ hopanes and steranes in their stable steric configurations in the four cores in the Changjiang Estuary, reflects a mixture of immature and mature organic matter.

A comparison of the hopanes and steranes parameters reveals several significant differences in the four sites (Table 6). The ratios of $\mathrm{Tm} / \mathrm{Ts}, 17 \beta$ $22,29,30$-trinorhopane $/ \mathrm{Ts}(17 \beta(\mathrm{H}) / \mathrm{Ts})$ and $22,29,30$ trinor-hop-5(6)-ene/Ts $\left(\mathrm{C}_{27}\right.$-hopene/Ts $)$ are usually thought to be thermal degradation parameters of organic matter (Seifert and Moldowan, 1980). However, they can be used to represent the bacterial alteration to hydrocarbons and the anoxic condition in recent sediment (Duan et al., 1996). In the four sites of the Changjiang Estuary, the ratios of $\mathrm{Tm} / \mathrm{Ts}$ are similar, while those of $17 \beta(\mathrm{H}) / \mathrm{Ts}$ and $\mathrm{C}_{27^{-}}$ hopene/Ts are different (Table 6$)$. The average ratios of $17 \beta(\mathrm{H}) / \mathrm{Ts}$ and $\mathrm{C}_{27}$-hopene/Ts are much higher in Sites 17 and 26, while they are lower in Sites 8 and 11, especially in Site 11. This result suggests that the sediment from Sites 17 and 26 is in relatively stronger anoxic conditions than the sediment from Sites 11 and 8, and that the bacterial activity is much stronger in Site 11 in spite of the source difference. However, all the sediments from the same core are not in the same conditions (Fig. 7). Obviously, the sediments from Sites 17 and 26 are in strong anoxic conditions from the depth of $40 \mathrm{~cm}$ to $106 \mathrm{~cm}$, and sediments from Site 8 are in strong anoxic conditions from the depth of $72 \mathrm{~cm}$ to $140 \mathrm{~cm}$. The result suggests that the particularly high ratios of $17 \beta(\mathrm{H}) / \mathrm{Ts}$ and $\mathrm{C}_{27}$-hopene/Ts may be due to the rich input of bacteria and plankton (Duan et al., 1996).
The epimer ratios of the $22 \mathrm{~S}$ to $22 \mathrm{~S}$ plus $22 \mathrm{R}$ $17 \alpha, 21 \beta$-homohopanes (C31 $\alpha \beta$-hopane 22S/22 $(\mathrm{S}+\mathrm{R}))$ are maturity parameters as well as the ratios of $20 \mathrm{~S}$ to $20 \mathrm{~S}$ plus 20R 24-ethyl$5 \alpha, 14 \alpha, 17 \alpha$-cholestanes $\left(\mathrm{C}_{29} \alpha \alpha \alpha\right.$-sterane $20 \mathrm{~S} / 20$ $(\mathrm{S}+\mathrm{R}))$. The ratios of $5 \alpha, 14 \beta, 17 \beta /(5 \alpha, 14 \beta, 17 \beta+$ $5 \alpha, 14 \alpha, 17 \alpha)$ 24-ethylcholestanes $\left(\mathrm{C}_{29}\right.$-sterane $\alpha \beta \beta /(\alpha \beta \beta+\alpha \alpha \alpha))$ represent the isomer parameter which is sensitive to bacteria and microbes in immature samples (Mackenzie et al., 1980; Seifert and Moldowan, 1980). The three parameters can also be used to represent the degree of bacterial degradation in recent sediment with little thermal action. In the four cores, the distributions of the average values of the three parameters are similar, and the values lower than their equilibrium ones are typical of oils from the Monterey Formation (Rullkötter et al., 2000), which shows the immature characteristics of organic matter subjected to bacterial degradation in recent sediment. However, the results obtained from the vertical distributions of the three parameters have few differences (Fig. 7). The result from $\mathrm{C}_{31} \alpha \beta$-hopane $22 \mathrm{~S} / 22(\mathrm{~S}+\mathrm{R})$ is consistent with that from the ratios of $\mathrm{Ts} / \mathrm{Tm}, 17 \beta(\mathrm{H}) / \mathrm{Ts}$ and $\mathrm{C}_{27}$-hopene/Ts, which is a little different from that obtained from the ratios $\mathrm{C}_{29} \alpha \alpha \alpha$-sterane $20 \mathrm{~S} / 20(\mathrm{~S}+\mathrm{R})$ and $\mathrm{C}_{29}$-sterane $\alpha \beta \beta /(\alpha \beta \beta+\alpha \alpha \alpha)$, especially in Site 8 . The ratios of $\mathrm{C}_{29} \alpha \alpha \alpha$-sterane $20 \mathrm{~S} / 20(\mathrm{~S}+\mathrm{R})$ remain invariable downwards in core 26, and slowly decrease downwards in core 8 except at the depth of $140 \mathrm{~cm}$, which shows that the epimerous processes of steranes are different from those of hopanes. The ratios of $\mathrm{C}_{29}$-sterane $\alpha \beta \beta /(\alpha \beta \beta+\alpha \alpha \alpha)$ obviously decrease downwards in core 8 , which shows that the steranes evolve from unstable steric configurations to stable ones in the early diagenetic processes in the deep marine sediment. 

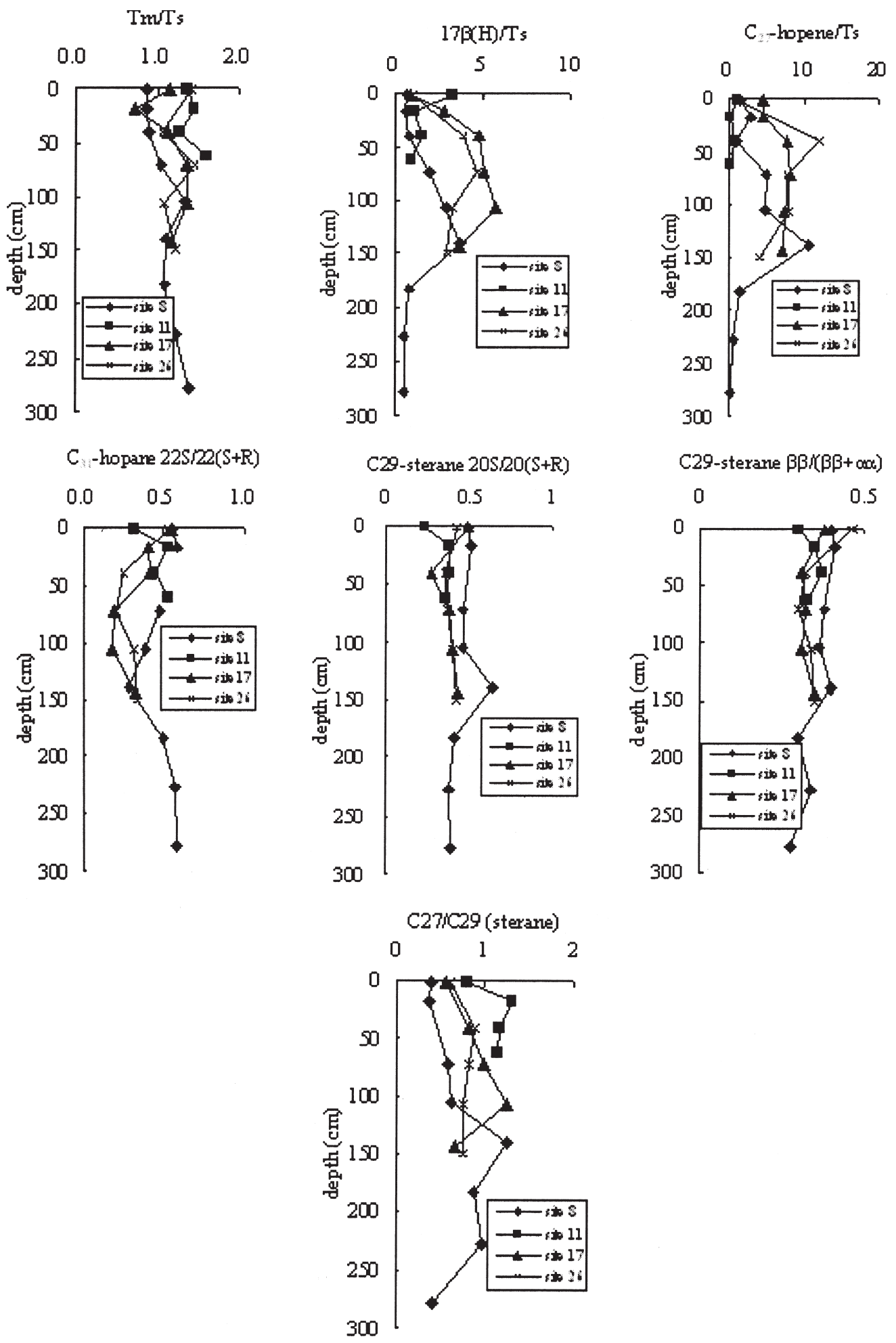

FIG. 7. - The vertical distributions of hopane and sterane parameters in the four cores of the Changjiang Estuary.

Steranes in sediment mainly come from the sterols in organisms. Generally, $\mathrm{C}_{27}$ steranes are indicative of a zooplankton and algae source (Gagosian et al., 1983; Volkman, 1986). $\mathrm{C}_{29}$ steranes are thought to originate from higher plants and dia- tioms (Volkman, 1986; Rieley et al., 1991; Volkman et al., 1999). The ratios of $\mathrm{C}_{27} / \mathrm{C}_{29}$ steranes can be used to estimate the origins or the degradation level of organic matter (Nichols et al., 1990). In the four cores, the average ratios of $\mathrm{C}_{27} / \mathrm{C}_{29}$ steranes are high- 
est in core 11, and lowest in core 8 , which suggests that the bacterial activity is active to improve the reduction of sterols in Site 11 based on the fact that there is much more terrestrial input. The vertical distributions of $\mathrm{C}_{27} / \mathrm{C}_{29}$ steranes are similar to those of $17 \beta(\mathrm{H}) /$ Ts except in core 11 , which indicates that the $\mathrm{C}_{27}$ sterols are easily deoxidized to $\mathrm{C}_{27}$ steranes in the relative anoxic conditions without considering the source difference. Obviously, the $\mathrm{C}_{27} / \mathrm{C}_{29}$ steranes are lower in the surface sediment, which may also be because steranes are the hydrogenation products of sterols, and do not originate directly from organisms. The difference between the distributions of shorter chain/longer chain $n$-alkanes ratios and the $\mathrm{C}_{27} / \mathrm{C}_{29}$ steranes ratios may also be ascribed to this reason.

\section{CONCLUSION}

The bulk and molecular organic geochemical study of marine sediments from four cores of the Changjiang Estuary shows that the organic matter consists in different mixtures from autogenic and terrestrial sources, and the four cores are all in anoxic condition. In core 8 and 26, the organic matter originates from the autogenic and allochthonous input, which has almost the same contribution to the organic matter source. In Site 11, there are many terrestrial plants subsided here carried by the Changjiang water. In Site 17, the organic matter mainly originates from the ancient Changjiang delta residue matter.

The distributions of molecular compounds show that the organic matter is in mixtures of immature and mature matter in the samples of the four cores, which also indicates that the microbial activity is active in anoxic conditions, especially in the surface sediment. The vertical distributions of molecular compounds also show that the autogenic marine organic matter is more easily degraded and molecular compounds evolve from unstable steric configurations to stable ones in the early diagenetic processes. The difference between the vertical distributions of different molecular biomarker ratios may be due to 1) the different circumstances at different depths; 2) the complex degradation processes of different molecular biomarkers; 3) their different sensitivities to the circumstances; 4) and the particular organic matter input of bacteria and plankton in different geological periods.

\section{ACKNOWLEDGEMENT}

We thank Professor Yi Duan from the Lanzhou Institute of Geology, Chinese Academy of Sciences for his help in making sample analyses and composition identification. This program was supported by the National Key Basic Research and Development Plan in China ("973" Project) (2002CB412409).

\section{REFERENCES}

Brassell, S.C. - 1993. Applications of biomarkers for delineating marine paleoclimatic fluctuations during the Pleistocene. In: M.H. Engel and S.A. Macko (eds.), Organic Geochemistry, pp. 699-738. Principles and Applications. Plenum, New York.

Canuel, E.A., K.H. Freeman and S.G. Wakeham. - 1997. Isotopic composition of lipid biomarker compounds in estuarine plants and surface sediments. Limnol. Oceanogr., 42: 1570-1583.

Chen, J.Y., H.T. Shen, and C.X.Yu. - 1988. Processes of Dynamics and Geomorphology of the Changjiang Estuary. Shanghai Scientific and Technological Publisher, Shanghai, pp. 454. (in Chinese with English abstract).

Chen, Q., S. Zhang, R. Huang and B. Chen. - 2002. Distribution of chemical substances in the low-salinity reach of Changjiang Estuary. Mar. Environ. Sci., 21: 29-33. (in Chinese with English abstract)

Cranwell, P.A., G. Eglinton and N. Robinson. - 1987. Lipids of aquatic organisms as potential contributors to lacustrine sediments- II. Org. Geochem., 11: 513-527.

Didyk, B.M., B.R.T. Simoneit, S.C. Brassell and G. Eglinton. 1978. Organic geochemical indicators of paleoenvironmental conditions of sedimentation. Nature, 272: 216-222.

Duan, Y. - 2000. Organic geochemistry of recent marine sediments from the Nansha Sea, China. Org. Geochem., 31: 159-167.

Duan, Y., B. Luo, Y. Xu and L.Ma. - 1996. Composition and geochemical significance of biomarkers in marine sediments from Nansha Islands waters, the South China Sea. Chin. J. Oceanol. Limnol., 27: 258-263. (in Chinese with English abstract)

Eisma, D. - 1998. Intertidal Deposits: River Mouths, Tidal Flats and Coastal Lagoons. CRC Press, Boca Raton, Florida.

Freudenthal, T., T. Wagner, F. Wenzhöfer, M. Zabel and G. Wefer. 2001. Early diagenesis of organic matter from sediments of the eastern subtropical Atlantic: Evidence from stable nitrogen and carbon isotopes. Geochim. Cosmochim. Acta, 65: 1795-1808.

Gagosian, R.B., J.K. Volkman and G.E. Nigrelli. - 1983. The use of sediment traps to determine sterol sources in coastal sediments off Peru. In: M. Bjorøy et al. (eds.), Advances in Organic Geochemistry, pp. 369-379. Wiley, Chichester.

González-Vila, F.J., O. Polvillo, T. Boski, D. Moura and de J.R. Andrés. - 2003. Biomarker patterns in a time-resolved Holocene/terminal Pleistocene sedimentary sequence from the Guadiana river estuarine area (SW Portugal/Spain border). Org. Geochem., 34: 1601-1613.

Grimal, J. and J. Albaigés. - 1987. Sources and occurrence of $\mathrm{C}_{12}{ }^{-}$ $\mathrm{C}_{22} n$-alkane distributions with even carbon-number preference in sedimentary environments. Geochim. Cosmochim. Acta, 55: 1379-1384.

Harada, N., N. Handa, M. Fukuchi and R. Ishiwatari. - 1995. Source of hydrocarbons in marine sediments in Lützow-Holm Bay, Antarctica. Org. Geochem., 23: 229-237.

Haven, ten H.L., de J.W. Leeuw, J. Rullkötter and J.S. SinningheDamsté. - 1987. Restricted utility of the pristine/phytane ratio as a paleoenvironmental indicator. Nature, 330: 641-643.

Hedges, J.I. and R.G. Keil. - 1995. Sedimentary organic matter preservation: an assessment and speculative synthesis. Mar, Chem., 49: 81-115.

Hedges, J.I. and R.G. Keil. - 1999. Organic geochemical perspectives on estuarine processes: sorption reaction and consequences. Mar. Chem., 65: 55-65.

Jaffé, R., G.A. Wolff, A.C. Cabrera and H. Carvajal-Chitty. - 1995. The biogeochemistry of lipids in rivers from the Orinoco Basin. 
Geochim. Cosmochim. Acta, 59: 4507-4522.

Jin, X. - 1992. Marine Geology of the East China Sea. pp. 185-219. China Ocean Press, Beijing, China.

Lehmann, M.F., S.M. Bernasconi, A. Barbieri and J.A. McKenzie. 2002. Preservation of organic matter and alteration of its carbon and nitrogen isotope composition during simulated and in situ early sedimentary diagenesis. Geochim. Cosmochim. Acta, 66: 3573-3584.

Li, M., S.R. Larter, P. Taylor, D.M. Jones, B. Bowler and M. Bjoroy. 1995. Biomarkers or not biomarkers? A new hypothesis for the origin of pristine involving derivation from methyltrimethyltridecylchromans (MTTCs) formed during diagenesis from chlorophyll and alkylphenols. Org. Geochem., 23: 159-167.

Logan, G.A. and G. Eglinton. - 1994. Biogeochemistry of the Miocene lacustrine deposit at Clarkia, northern Idaho, USA. Org. Geochem., 21: 857-870.

Lü, X, J. Song, X. Li, H. Yuan, T. Zhan, N. Li and X. Gao. - 2005. Geochemical characteristics of nitrogen in the southern Yellow Sea surface sediments, J. Mar. Syst., 56: 17-27.

Lü, X. and J. Song. - 2004. The effect of circumstance on the formation and release of transferable nitrogen in different grain size surface sediments of the southern Yellow Sea. Environ. Chem., 23: 314-320. (in Chinese with English abstract).

Lü, X and S. Zhai. - 2005. Sources and transport of hydrocarbons in sediments from the Changjiang River Estuary, China. Mar. Pollut. Bull., 50: 1738-1744.

Mackenzie, A.S., R.L. Patience, J.R. Maxwell, M. Vandenbroucke and B. Durand. - 1980. Molecular parameters of maturation in the Toacian shales, Paris Basin, France. I. Changes in the configurations of acyclic isoprenoid alkanes, steranes and triterpanes. Geochim. Cosmochim. Acta, 44: 1709-1721.

Mangelsdorf, K. and J. Rullkötter. - 2003. Natural supply of oilderived hydrocarbons into marine sediments along the California continental margin during the late Quaternary. Org. Geochem., 34: 1145-1159.

Mannio, A. and H.R. Harvey. - 1999. Lipid composition in particulate and dissolved organic matter in the Delaware Estuary: Sources and diagenetic patterns. Geochim. Cosmochim. Acta, 63: 2219-2235.

Medeiros P.M. and M.C. Bícego. - 2004. Investigation of natural and anthropogenic hydrocarbon inputs in sediments using geochemical markers. I. Santos, SP-Brazil. Mar. Poll. Bull., 49: 761-769.

Medeiros, P.M., M.C. Bícego, R.M. Castelao, C.D. Rosso, G. Fillmann and A.J. Zamboni. - 2005. Natural and anthropogenic hydrocarbon inputs to sediments of Patos Lagoon Estuary, Brazil. Environ. Int., 31: 77-87.

Meyers, P.A. - 1994. Preservation of elemental and isotopic source identification of sedimentary organic matter. Chem. Geol., 144: 289-302.

Meyers, P.A. - 1997. Organic geochemical proxies of paleoceanographic, paleolimnologic and paleoclimatic processes. Org. Geochem., 27: 213-250.

Meyers, P.A. and R. Ishiwatari. - 1993. Lacustrine organic geochemistry-an overview of indicateors of organic matter sources and diagenesis in lake sediments. Org. Geochem., 20: 867-900.

Müller, P.J. - 1977. C/N ratios in Pacific deep-sea sediments: Effect of inorganic ammonium and organic nitrogen compounds sorbed by clays. Geochim. Cosmochim. Acta, 41: 765-776.

Muri, G., S.G. Wakeham, T.K. Pease and J. Faganeli. - 2004. Evalution of lipid biomarkers as indicators of changes in organic matter delivery to sediments from Lake Planina, a remote mountain lake in NW Slovenia. Org. Geochem., 35: 1083-1093. Nichols, P.D., A.C. Palmisano, M.S. Rayner, G.A. Smith and D.C. Vhite. - 1990. Occurrence of novel C30sterols in Antarctic seaice diatom communities during a spring bloom. Org. Geochem., 15: 503-508.

Nieuwenhuize, J., Y.E.M. Maas and J.J. Middelburg. - 1994. Rapid analysis of organic carbon and nitrogen in particulate materials. Mar. Chem., 45: 217-224.

Peters, K.E. and J.M. Moldowan. - 1993. The Biomarker Guide. Interpreting Molecular Fossils in Petroleum and Acient Sediments. pp. 363. Prentice Hall, Englewood Cliffs, NJ.

Rieley, G., R.J. Collier, D.M. Jones and G. Eglinton. - 1991. The biogeochemistry of Ellesmere Lake, U.K.- I. Source correlation of leaf wax inputs to the sedimentary lipid record. Org. Geochem., 17: 901-912.

Rullkötter, J., P. Sundararaman, M. Radke and R.G. Sckaefer. 2000. Maturity assement of Monterey crude oils using biological marker parameters. In: Isaacs C.M. and J. Rullkötter (eds.), The Monterey Formation-From Rocks to Molecules. pp. 329347. Columbia University Press, USA.

Seifert, W.K. and J. Moldowan. - 1980. The effect of thermal stress on source rock quality as measured by hopane stereochemistry. In: Douglas A.G. and J.R. Maxwell (eds.), Advances in Organic Geochemistry 1979. pp. 229-237. Pergamon Press, Oxford.

Steinhauer, M.S., Boehm P.D. (1992) The composition and distribution of saturated and aromatic hydrocarbons in nearshore sediments, river sediments, and coastal peat of Alaskan Beaufort Sea: implications for detecting anthropogenic hydrocarbon inputs. Mar. Environ. Res., 33: 223-253.

The Specification for Marine Monitoring (HY003.1-91 HY/T 003.10-91) -1991. Pp. 397-399. Beijing, China Ocean Press (in Chinese).

Twichell, A.C., P.A. Meyers and L. Diester-Haass. - 2002. Significance of high $\mathrm{C} / \mathrm{N}$ ratios in organic-carbon- rich Neogene sediments under the Benguela Current upwelling system. Org. Geochem., 33: 715-722.

Verardo, D.J. and A. McIntyre. - 1994. Production and preservation: control of biogenous sedimentation in the tropical Atlantic 0-300000 years B.P. Paleoceanogr., 9: 63-86.

Volkman, J.K. - 1986. A review of sterol markers for marine and terrigenous organic matter. Org. Geochem., 9: 83-99.

Volkman, J.K. and J.R. Maxwell. - 1986. Acyclic isoprenoids as biological markers. In: Johns, R.B. (ed.), Biological Markers in the Sedimentary Record. pp. 1-42. Elsevier, Amsterdam,

Volkman, J.K., P. Kearney and S.W. Jeffrey. - 1990. A new source of 4-methyl sterols and $5 \alpha(\mathrm{H})$-stanols in sediments: Prymnesiophyte microalgae of the genus Pavlova. Org. Geochem., 15: 489-497.

Volkman, J.K., S.M. Barret and S.I. Blackburn. - 1999. Eustigmatophyte microalgae are potential sources of $\mathrm{C}_{29}$ sterols, $\mathrm{C}_{22}-\mathrm{C}_{28}$ n-alcohols and $\mathrm{C}_{28}-\mathrm{C}_{32}$ n-alkyl diols in freshwater environments. Org. Geochem., 30: 307-318.

Wang, B., R. Zhan and J. Zang. - 2002. Distributions and transportation of nutrients in Changjiang River Estuary and its adjacent sea area. Acta Oceanol. Sinica, 24: 53-58. (in Chinese with English abstract)

Zhao, B.G., Ren, D. Cao and Y. Yang. - 2001. Characteristics of the ecological environment in upwelling area adjacent to the Changjiang River Estuary. Chinese J. Oceanol. Limnol., 32: 327-333. (in Chinese with English abstract).

Scien. ed.: J. Albaigés 